\title{
Threshold Requirements for Burning Downed Honey Mesquite
}

\author{
GUY R. MCPHERSON AND HENRY A. WRIGHT
}

Forty-one headfires were burned on 0.1-ha test plots on 2 west Texas study sites in the spring of 1984 . The purpose of these burns was to develop a prescription for predicting whether downed honey mesquite will be consumed by a prescribed fire. It was found, using regression analysis and discriminant analysis techniques, that critical variables for predicting ignition and combustion of downed honey mesquite are: (1) windspeed, (2) stem moisture content, (3) stem diameter, and (4) proportion of green fuel in the fuel bed. Threshold values for ignition were $6 \mathrm{~km} / \mathrm{hr}$ windspeed, $6 \%$ stem surface moisture content, $5 \mathrm{~cm}$ stem diameter, and $15 \%$ green:total fine fuel. Threshold values for sustained combustion were $15 \mathrm{~km} / \mathrm{hr}$ windspeed, $6 \mathrm{~cm}$ stem diameter, and $6 \%$ stem moisture content at $1.25 \mathrm{~cm}$ below the stem surface. A prescription for burning downed honey mesquite was developed.

Honey mesquite (Prosopis glandulosa var. glandulosa) is a serious management problem in west Texas. Mesquite reduces water availability, impairs livestock handling (Fisher et al. 1973), and decreases grass production (Dahl et al. 1978). Mechanical methods of control (root plowing, chaining, dozing, rollerchopping) have been used extensively to control mesquite. Annually, over 133,000 acres of mesquite-infested rangeland were treated with mechanical methods from 1973 to 1978 (Hoffman 1978). Mechanical control increases available water and improves visibility, but residual woody debris hampers maneuverability and reduces the amount of pasture surface available to grow forage. Prescribed burning is a relatively inexpensive management tool which can be used to remove debris. Downed mesquite can be burned more easily than standing mesquite (Heirman and Wright 1973) but descriptive models for predicting mesquite consumption are lacking. This research was conducted to determine threshold prescription requirements for burning downed honey mesquite.

\section{Methods}

Forty-one, 0.1-ha plots were burned on 2 west Texas study sites in spring 1984. Fifteen plots were burned in a chained mesquite/tobosagrass community $10 \mathrm{~km}$ south of Gail, Borden County, on the Beale Brothers Ranch; 26 plots were burned in a tree-dozed mesquite/mixed grass community $11 \mathrm{~km}$ north of Snyder, Scurry County, on the Fuller Brothers East Ranch. All plots were burned as headfires on flat terrain.

West Texas climate is characterized by dry winters, with most of the moisture falling between April and October as a result of thunderstorm activity. Annual rainfall averages 30 to $50 \mathrm{~cm}$, but precipitation varies widely (Orton 1973,1975 ).

The Gail study site was chained about 1940. At the time of burning, the site was dominated by tobosograss (Hilaria mutica). A few species of annual grasses and forbs were present. Soils on this site are Stamford clays (fine, montmorillonitic, thermic Typic Chromusterts), Mangum clays (fine, mixed, thermic Vertic Ustochrepts), and Vernon clays (fine, mixed, thermic Typic Ustochrepts) (Dixon 1975).

The Snyder study site was tree-dozed in the late 1960's. Predominant vegetation comprising the fuel bed included sideoats grama (Bouteloua curtipendula), threeawn (Aristida sp.), little bluestem (Schizachyrium scoparium), silver bluestem (Bothriochloa saccharoides), vine mesquite (Panicum obtusum), buffalograss (Buchloe dactyloides), pink pappusgrass (Pappophorum bicolor), Canada wildrye (Elymus canadensis), Texas wintergrass (Stipa leucotri-

\footnotetext{
Authors are research assistant and chairperson, Department of Range and Wildlife Texas Tech University, Lubbock 79409. This study is a contribution of the College of
Agricultural Sciences, Texas Tech University, No. T-9-396.

Manuscript accepted 16 December 1985.
}

cha), rescue grass (Bromus unioloides), and dropseeds (Sporobolus spp.). Predominant soils on this site are Weymouth (fineloamy, mixed, thermic Typic Ustochrepts) and Vernon clay loams and clays of the Vernon-Badland complex. Colorado (fine-loamy, mixed, thermic Fluventic Haplustolls) and Spur (fine-loamy, mixed calcareous, thermic Typic Ustifluvents) soils occupy a minor portion of this site (Dixon et al. 1973).

Wood borer activity in mesquite wood lowers ignition time (Burton et al. 1972) by increasing surface area-to-volume ratio and decreasing thermal conductivity of sapwood (Ueckert and Wright 1974). Presumably, wood borers decrease specific gravity over time. Borer activity was quantified by calculating specific gravity of $27,5-\mathrm{cm}$ stems for each site. Specific gravity of each stem was determined by weighing in mercury (Browning 1967):

$$
S G=13.55 \times \text { ovendry weight } / \text { weight in mercury. }
$$

Samples were arranged in a completely randomized design with 9 samples in each of 3 replications. Tukey's procedure was used to test for differences between treatment sites (Steel and Torrie 1980).

Brown's (1974) planar-intersect technique was used to inventory downed woody fuel on each plot. Depending on the amount of woody fuel in each plot, one to four 10-m permanent transects were rand omly established through accumulations of chained mesquite. Height above ground and diameter of each downed mesquite stem which intercepted the transect were recorded. This inventory estimated the total woody fuel load and height of each stem. The equation for estimating woody fuel volume was derived from Brown (1974):

\section{$V=0.7369 \Sigma d^{2}$, where}

$V=$ volume $\left(\mathrm{m}^{3} / \mathrm{ha}\right)$ and

$\mathrm{d}=$ diameter of individual stems $(\mathrm{cm})$.

Immediately before burning, several measurements were taken to describe environmental conditions. Relative humidity and air temperature were measured with a sling psychrometer. Average windspeed $2 \mathrm{~m}$ above ground was recorded with a totalizing anemometer (Clark et al. 1981). Solar intensity was measured with a radiometer (LI-COR n.d.).

Fine fuel load was estimated by clipping, to within $1 \mathrm{~cm}$ of soil surface, four $0.10-\mathrm{m}^{2}$ quadrats adjacent to woody fuel transects. Fine fuel from each quadrat was separated into green, standing dead, and mulch components in the laboratory. Herbaceous material was oven-dried to constant weight at $60^{\circ} \mathrm{C}$ and weighed to the nearest $1 \mathrm{~g}$. Phenological stage of the grass stand was characterized by the proportion of green fuel in the fuel bed. Subsamples of each component were weighed in the field immediately after clipping, oven-dried at $60^{\circ} \mathrm{C}$ to constant weight, then reweighed to determine fine fuel moisture content on a dry-weight basis.

Moisture content of mesquite stems was measured with a Mini Protimeter hand-held moisture meter (Clark and Roberts 1982). Moisture content of a $15-\mathrm{cm}$ diameter stem was measured at the surface, at $1.25 \mathrm{~cm}$, and at $2.5 \mathrm{~cm}$ below the surface. A hammer probe with insulated prongs was used for below-surface measurements. Measurements at these locations were recorded for the top, bottom, and both sides of the stem.

Within 2 weeks of burning, inventory of woody fuel along the permanent transect lines was repeated. Ignition and sustained combustion of each stem was noted, as well as diameter of partially burned stems. Ignition was defined by presence of charcoal on a stem. Combustion was sustained if stem diameter was reduced at least $1 \mathrm{~cm}$ where the sampling plane intercepted the stem. Percent consumption along transects was calculated by: 
$\mathrm{C}=\left(\left(1-\left(\mathrm{V}^{\prime} / \mathrm{V}\right)\right) \times 100 \%\right.$, where

$\mathrm{C}=$ consumption $(\%)$,

$\mathrm{V}=$ initial (pre-burn) volume $\left(\mathrm{m}^{3} / \mathrm{ha}\right)$, and

$V^{\prime}=$ final (post-burn) volume $\left(\mathrm{m}^{3} / \mathrm{ha}\right)$.

A predictive model for ignition of individual stems was generated by the Biomedical Computer Programs (BMDP) stepwise disciminant analysis program (Jennrich and Sampson 1981). Ignition (dependent variable) was compared to independent variables listed in Table 1. For stems which ignited, discriminant analysis was used to relate sustained combustion to independent variables.

Table 1. Independent variables considered in analy zing ignition, sustained combustion, and percent consumption of downed honey mesquite in west Texas.

\begin{tabular}{|c|c|c|}
\hline \multirow{2}{*}{$\frac{\text { Variable }}{\text { Air temperature }\left({ }^{\circ} \mathrm{C}\right)}$} & \multicolumn{2}{|c|}{ MinimumMaximum } \\
\hline & 12.7 & 29.4 \\
\hline Relative humidity (\%) & 15.0 & 60.0 \\
\hline Average windspeed $2 \mathrm{~m}$ above soil surface $(\mathrm{km} / \mathrm{hr})$ & 0.0 & 29.7 \\
\hline Solar intensity $\left(\mathbf{W} / \mathbf{m}^{2}\right)$ & 0.5 & 899.0 \\
\hline Fine fuel load, standing dead material (kg/ha) & 100.0 & $15,282.0$ \\
\hline Fine fuel load, mulch (kg/ha) & 683.0 & $8,845.0$ \\
\hline Fine fuel load, green material ( $\mathrm{kg} / \mathrm{ha}$ ) & 0.0 & $2,000.0$ \\
\hline Fine fuel load, total $(\mathrm{kg} / \mathrm{ha})$ & $1,424.0$ & $23,390.0$ \\
\hline Proportion green material:total fine fuel load (\%) & 0.0 & 28.7 \\
\hline Moisture content, standing dead material (\%) & 2.0 & 14.0 \\
\hline Moisture content, mulch (\%) & 2.0 & 31.0 \\
\hline Moisture content, green material $(\%)$ & 144.0 & 291.0 \\
\hline Stem moisture content, surface $(\%)$ & 4.0 & 8.0 \\
\hline Stem moisture content, $1.25 \mathrm{~cm}$ depth $(\%)$ & 4.0 & 8.0 \\
\hline Stem moisture content, $2.5 \mathrm{~cm}$ depth $(\%)$ & 9.5 & 20.0 \\
\hline Stem diameter $(\mathrm{cm})$ & 0.3 & 25.4 \\
\hline Stem height $(\mathrm{cm})$ & 0.0 & 92.0 \\
\hline
\end{tabular}

Stems were categorized into 2 groups-ignition vs. nonignition and continued combustion vs. nonsustained combustion-for the 2 analyses. When a large number of independent variables are used in stepwise discriminant analysis, 3 to 5 independent variables should be selected to minimize noise (Lachenbruch 1975). Therefore an attempt was made to predict ignition and combustion of individual stems based on the most reliable 3 to 5 variables. Dual discriminant functions were combined into single equations to simplify interpretation of results (Morrison 1976). The jackknifed classification method, which generates functions on all data except the stem being classified, was used because it provides a more realistic estimate of the ability of predictive variables to discriminate between groups (Tabachnick and Fidell 1983).

The Statistical Analysis System (SAS) stepwise multiple regression program (Ray 1982) was used to analyze consumption along transects. Percent consumption (dependent variable) was regressed against independent variables (Table 1).

\section{Results and Discussion}

Specific gravity for both sites averaged 0.635 . No significant $(P<0.05)$ differences were found between sites. Specific gravity was less than that reported by Clark (1981) for sound mesquite wood $(0.70)$, indicating that borer activity decreases specific gravity of mesquite over time. There was no difference between sites treated 20 and 40 years ago. Assuming population size and activity level of borers were the same for the 2 sites, it appears that the effect of wood borers on specific gravity stabilizes prior to 20 years post-treatment.

\section{Individual Stem Analysis}

A four-variable function correctly classified $77 \%$ of the 1,260 stems analyzed. The function predicts a stem will ignite if:

$$
0.0293 W S+0.1666 \mathrm{D}-0.8795 \mathrm{AS}-2.5028 \mathrm{R}+2.608>0 \text {, }
$$

Where:

WS $=$ windspeed at $2 \mathrm{~m}$ height $(\mathrm{km} / \mathrm{hr})$,

$\mathrm{D}=$ diameter of stem $(\mathrm{cm})$,

AS = surface moisture content of stem $(\%)$, and

$\mathbf{R}=$ proportion green fuel:total fuel load (fraction).

Figure 1 illustrates conditions conducive to stem ignition.

Increasing windspeed and decreasing stem moisture content increased ignition. Stem moisture content had a threshold value at $6 \%$. Only $54 \%$ of stems with greater than $6 \%$ moisture content ignited; stems with $6 \%$ or less moisture content ignited $90 \%$ of the

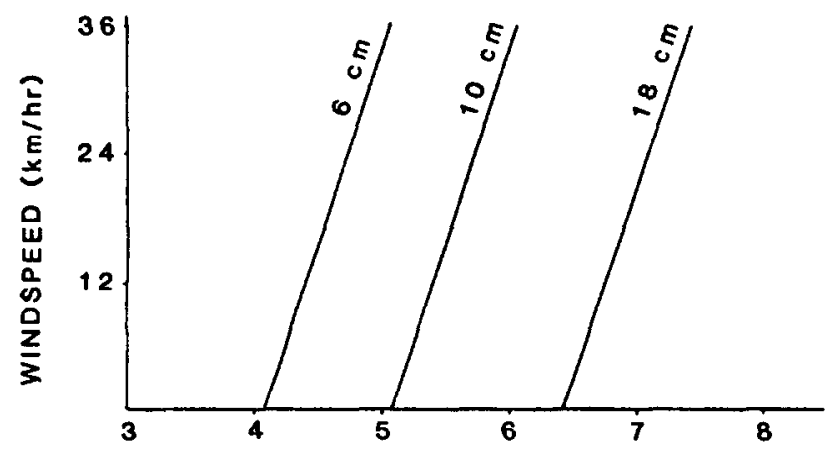

SURFACE STEM MOISTURE CONTENT (\%)

Fig. 1. Conditions required to ignite downed mesquite stems in west Texas. Ignition occurs at points to the left of stem diameter lines. Lines assume $5 \%$ green fuel in a continuous fuel bed.

time. Large stems ignited more readily than small stems due to their rough and broken bark and increased wind eddying on the lee side. Small stems had smooth surfaces which were difficult to ignite. Clark (1981) found that small mesquite stems had lower specific gravity than large stems, which may have affected combustion. Ninety-three percent of stems $5 \mathrm{~cm}$ or larger ignited, whereas $63 \%$ of the stems smaller than $5 \mathrm{~cm}$ ignited. Increasing the proportion of green fuel decreased ignition, implying that early spring burns will ignite more stems than burns conducted after green-up.

Of 1,107 stems which ignited, 610 were completely consumed. A three-variable function correctly classified $63 \%$ of the stems. The model predicted that a stem would be completely consumed if:

$$
0.048667 \mathrm{WS}+0.04515 \mathrm{D}-0.298 \mathrm{M}+0.947>0,
$$

where:

WS = windspeed at $2 \mathrm{~m}$ height $(\mathrm{km} / \mathrm{hr})$,

$\mathrm{D}=$ diameter of stem $(\mathrm{cm})$, and

$\mathrm{M}=$ moisture content of stem, $1.25 \mathrm{~cm}$ depth (\%).

Figure 2 illustrates conditions required for sustained combustion of stems.

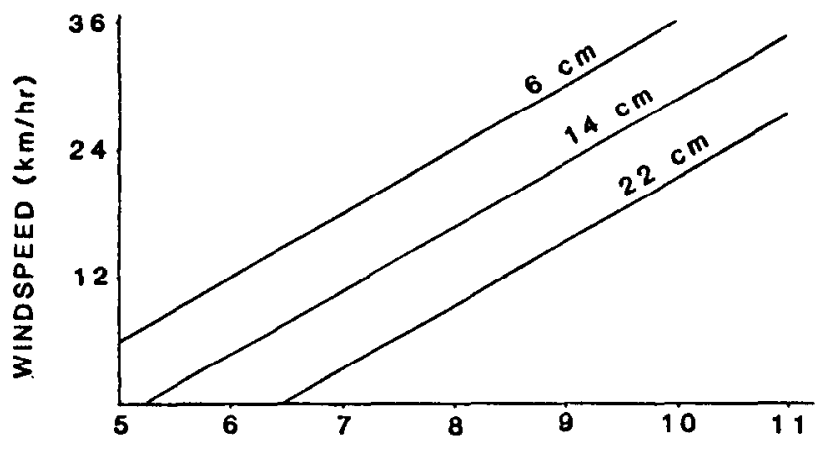

MOISTURE CONTENT, $1.25 \mathrm{CM}$ DEPTH $(\%)$

Fig. 2. Conditions required for sustained combustion of downed mesquite stems in west Texas. Combustion is sustained at points to the left of stem diameter lines. Lines assume prior ignition of stem. 
When stem moisture content decreased, combustion increased. This implied that a drying period prior to burning would increase consumption. The length of the drying period depends on temperature, relative humidity, windspeed, solar intensity, and the initial moisture content of the stem. In this study, moisture content at $1.25 \mathrm{~cm}$ dropped from $8 \%$ to $6 \%$ in a dry 5 -day period, and from $6 \%$ to $4 \%$ in the next 5 -day period. Beyond some low moisture content increased drying will probably not result in increased combustion. However, that value was not achieved in this study.

This analysis assumes stem ignition; therefore, fine fuel characteristics were not important in determining if combustion will be sustained for this analysis. It should be noted that high winds were required for sustained combustion of a stem when moisture content at $1.25 \mathrm{~cm}$ exceeded $10 \%$ (Fig. 2). Small stems were difficult to consume, probably due to minimal re-radiation with the soil surface and other burning woody material.

Threshold values for sustained combustion were apparent for windspeed, stem diameter, and stem moisture content. Windspeed greater than $15 \mathrm{~km} / \mathrm{hr}$ sustained combustion in $87 \%$ of the stems. Only $35 \%$ continued burning when windspeed fell below $15 \mathrm{~km} / \mathrm{hr}$. Stems greater than $6 \mathrm{~cm}$ in diameter sustained combustion $81 \%$ of the time. By contrast, $42 \%$ of the stems less than $6 \mathrm{~cm}$ burned continuously. Stems with moisture content less than $6 \%$ sustained combustion $72 \%$ of the time; $27 \%$ of the stems continued to burn when moisture content exceeded $6 \%$.

\section{Consumption}

Consumption varied from $0 \%$ to $100 \%$ on the 87 transects analyzed. Windspeed was the most important variable for predicting percent consumption, accounting for $57 \%$ of the variability. The relationship between consumption and windspeed appeared to be exponential (Fig. 3). Therefore the SAS nonlinear least-squares

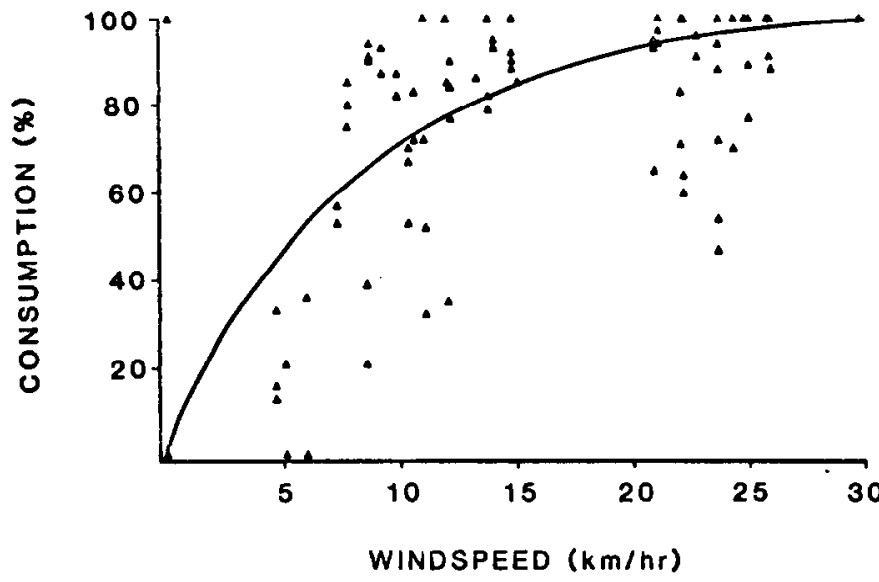

Fig.3. Relationship between average windspeed and percent consumption of downed honey mesquite, based on 41 headfires in west Texas.

procedure (Ray 1982) was used to fit a curve to the data. Windspeed and fine fuel moisture content (standing dead component) were the only significant $(P<0.05)$ variables for predicting consumption:

$$
C=3.0+118.81\left(1-\mathrm{e}^{-0.124 \mathrm{wg}}\right)-2.789 \mathrm{MS}, \text { where }
$$

$\mathrm{C}=$ consumption of woody debris $(\%)$,

WS = average windspeed $2 \mathrm{~m}$ above soil surface $(\mathrm{km} / \mathrm{ha})$, and

MS = fine fuel moisture content, standing dead (\%).

The model was significant $(\mathrm{P}<0.01)$ and had an $R^{2}$ of 0.59 . Inclusion of all variables into the model produced an $R^{2}$ of 0.67 .

Most of the literature concerning combustion of wildland fuels indicates stem moisture content is the most important variable affecting sustained combustion (e.g., Byram 1959, Pompe and Vines 1966, Van Wagner 1967). Although stem moisture content was important in predicting whether an individual stem would sustain combustion, it was not significant $(P<0.05)$ in predicting percent consumption. Stem moisture content was probably not high enough to become a limiting factor in this study; highest moisture content measured was $20 \%$. Vines (1981) indicated that moisture in fuels has only a small effect on combustion unless present in such large quantities that the fire is cooled as it proceeds. Mesquite apparently releases enough heat to evaporate water and sustain combustion, at least up to $20 \%$ moisture content.

To assure consumption of woody debris with a standard headfire prescription (air temperature $21-27^{\circ} \mathrm{C}$, relative humidity $25-40 \%$ ), windspeed should exceed $13 \mathrm{~km} / \mathrm{hr}$ and fine fuel moisture should be less than $10 \%$. Since fine fuel moisture is strongly positively related to relative humidity (Britton et al. 1973) burning late in the day when relative humidity is low will produce the best results. The National Fire Danger Rating System (Deeming et al. 1977) can be used to predict fuel moisture from environmental parameters. Total fine fuel load was weakly correlated with consumption, suggesting that although fine fuel load should be continuous enough to support fire spread, additional increases in fine fuel do not necessarily increase consumption. In this study, $100 \%$ consumption was obtained on a burn with only $223 \mathrm{~kg} / \mathrm{ha}$ of standing dead grass. The stand was continuous and was burned with safe headfire conditions (air temperature $24^{\circ} \mathrm{C}$, relative humidity $24 \%$, windspeed $22 \mathrm{~km} / \mathrm{hr}$ ).

\section{Recommendations}

Downed mesquite can be burned with less fine fuel and lower air temperature than standing mesquite. Before burning on a management-unit basis, several preliminary measurements should be taken to insure a successful burn. Moisture content of mesquite stems should be measured at the surface and at $1.25 \mathrm{~cm}$ below the stem surface. Stems rarely ignite if surface moisture content exceeds $9 \%$ and usually do not continue burning when $1.25-\mathrm{cm}$ moisture content is greater than $10 \%$. If direct measurement is not feasible, a small test plot should be burned to assure that sustained combustion will occur.

Pastures to be burned should be deferred from grazing for at least 1 growing season, to assure continuous fine fuel. Stands with less than $1,000 \mathrm{~kg}$ / ha fine fuel rarely support fire spread with safe burning conditions (Clark 1983). Increased fine fuel loads allow greater flexibility in prescribed burning and usually assure better fuel continuity.

Finally, windspeed should be measured before burning. Windspeed is the most critical variable for predicting consumption of downed mesquite. For best results, windspeed should be at least 13 $\mathrm{km} / \mathrm{hr}$. Windspeeds greater than $32 \mathrm{~km} / \mathrm{hr}$ are conducive to erratic fire behavior and should be avoided (Wright and Bailey 1980).

Stem diameter is important as a predictive variable, but cannot be controlled by the land manager. Under marginal burning conditions large stems will be consumed while small stems $(<5 \mathrm{~cm})$ may not ignite. Burning before green-up with windspeed greater than 18 $\mathrm{km} / \mathrm{hr}$ and stem moisture content less than $6 \%$ will assure ignition and consumption of all sizes of stems.

\section{Literature Cited}

Britton, C.M., C.M. Countryman, H.A. Wright, and A.C. Walkevar. 1973. The effect of humidity, air temperature, and wind speed on fine fuel moisture content. Fire Technol. 9:46-55.

Brown, J.K. 1974. Handbook for inventorying downed woody material. USDA Forest Serv. Gen. Tech. Rep. INT-16, 24 p. Intermt. Forest and Range Exp. Sta., Ogden, Utah.

Browning, B.L. 1967. Methods of wood chemistry. Vol. I, 384 p. Interscience Pub., New York.

Burton, C.E., W.M. Portnoy, and H.A. Wright. 1972. Borer activity and mesquite ignition parameters. Proc. South. Weed Sci. Soc. 25:303-313.

Byram, G.M. 1959. Combustion of forest fuels, p. 61-89. In: Forest Fire: Control and Use. McGraw-Hill Book Co., New York. 
Clark, R.G. 1981. Specific gravity of mesquite. In: C.M. Britton and F.S. Guthery (eds.), Research highlights-noxious brush and weed control, Vol. 12. Texas Tech Univ., Lubbock.

Clark, R.G. 1983. Threshold requirements for fire spread in grassland fuels. Ph.D. Diss. Texas Tech Univ., Lubbock.

Clark, R.G., and F.H. Roberts. 1982. A belt weather kit accessory for fuel moisture. Fire Manage. Notes 43:25-26.

Clark, R.G., A.A. Steuter, and C.M. Britton. 1981. An inexpensive anemometer frame. Fire Manage. Notes 42:13-14.

Dahl, B.E., R.E. Sosebee, J.P. Goen, and C.S. Brumley. 1978. Will mesquite control with 2,4,5-T enhance grass production? J. Range Manage. 31:129-131.

Deeming, J.E., R.E. Burgan, and J.D. Cohen. 1977. The National FireDanger Rating System-1978. USDA Forest Serv. Gen. Tech. Rep. INT-39, 63 p. Intermt. Forest and Range Exp. Sta., Ogden, Utah.

Dixon, M.L. 1975. Soil Survey of Borden County, Texas. USDA Soil Conserv. Serv.

Dixon, M.L., W.H. Dittemore, Jr., and H.W. Hyde. 1973. Soil Survey of Scurry County, Texas. USDA Soil Conserv. Serv.

Fisher, C.E., H.T. Wiedemann, C.H. Meadors, and J.H. Brock. 1973. Mechanical control of mesquite, p. 46-52. In: C.J. Scifres, R.W. Bovey, C.E. Fisher, G.O. Hoffman, and R.D. Lewis (eds.). Mesquite: growth and development, management, economics, control, uses. Texas Agr. Exp. Sta. Res. Monogr. 1, College Station.

Heirman, A.L., and H.A. Wright. 1973. Fire in medium fuels of west Texas. J. Range Manage. 26:331-335.

Hoffman, G.0. 1978. Texas brush and weed control acreages. Texas Agr. Ext. Serv. RM 3-1.

Jennrich, R., and P. Sampson. 1981. Stepwise discriminant analysis, p. 519-537. In: W.J. Dixon (ed.) Biomedical Computer Programs, P-series. Univ. Calif. Press, Berkeley.
Lachenbruch, P.A. 1975. Discriminant analysis. MacMillan Publ. Co., New York.

LI-COR. n.d. Instruction manual for LI-185 quantum/radiometer/photometer. Lambda Inst. Co., Lincoln, Nebr.

Morrison, D.F. 1976. Multivariate statistical methods, 2nd ed. McGrawHill, New York.

Orton, R.B. 1973. Climate. p. 53-54. In: Dixon, M.L., W.H. Dittemore, Jr., and H.W. Hyde, Soil Survey of Scurry County, Texas. USDA Soil Conserv. Serv.

Orton, R.B. 1975. Climate: p. 64-65. In: Dixon, M.L., Soil Survey of Borden County, Texas. USDA Soil Conserv. Serv.

Pompe, A., and R.G. Vines. 1966. The influence of moisture on the combusion of leaves. Aust. Forest. 30:231-241.

Ray, A.A. (ed.). 1982. SAS User's Guide: Statistics. Cary, North Carolina.

Tabachnick, B.G., and L.S. Fidell. 1983. Using multivariate statistics. Harper \& Row, New York.

Ueckert, D.N., and H.A. Wright. 1974. Wood boring insect infestations in relation to mesquite control practices. J. Range Manage. 27:383-386.

Van Wagner, C.E. 1967. Calculations on forest-fire spread by flame radiation. Can. Dep. Forest. Rural Devel, Pub. No. 1185.

Vines, R.G. 1981. Physics and chemistry of rural fires, p. 129-149. In: A.M. Gill, R.H. Graves, and I.R. Noble (eds). Fire and the Australian biota. Aust. Acad. Sci., Canberra City.

Wright, H.A., and A.W. Bailey. 1980. Fire ecology and prescribed burning in the Great Plains - a research review. USDA Forest. Serv. Gen. Tech. Rep. INT-77, 61 p. Intermt. Forest. and Range Exp. Sta. Ogden, Utah.

\title{
Vegetation Changes on Western Rangelands
}

\author{
by Farrel A. Branson
}

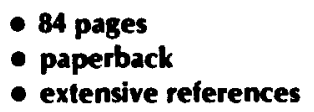

- illustrated
$-\$ 4.00$ postpaid

This book provides a comprehensive source of information on vegetation changes that have occurred on western rangelands during the past 100 years. It is illustrated with maps and photographs. The comments of one reviewer of the manuscript are as follows:

"It is a very good source of information on vegetation types for students as well as range professionals. It would be a good text for range community courses and portions could be used for selected assignments in other range courses. It brings together the primary references and provides so much more information to date than our present texts. I strongly believe that it will be a well-referred source. It would also improve the image of the range profession as one that is tremendously knowledgeable about the resources it manages. Branson's style of writing is good. It is straight forward and uncomplicated."-Dr. M. Hironaka, University of Idaho, Moscow, Idaho.

Range professors and students, private and public range managers, soil conservationists, wildlife managers, and others will find the book a valuable contribution to their libraries. Available from the Society for Range Management 2760 W. Fifth Ave., Denver, CO 80204. 